\title{
Hybrid
}

Revue des arts et médiations humaines

\section{Depicting existentiality: the anarchic aesthetic of Désordre by Philippe De Jonckheere}

\section{Corentin Lahouste}

\section{(2) OpenEdition \\ 1 Journals}

\section{Electronic version}

URL: https://journals.openedition.org/hybrid/465

DOI: $10.4000 /$ hybrid.465

ISSN: 2276-3538

This article is a translation of:

Dépeindre l'existentialité : l'esthétique anarchique de Désordre de Philippe De Jonckheere - URL :

https://journals.openedition.org/hybrid/472 [fr]

Publisher

Presses universitaires de Vincennes

\section{Electronic reference}

Corentin Lahouste, "Depicting existentiality: the anarchic aesthetic of Désordre by Philippe

De Jonckheere", Hybrid [Online], 5 | 2018, Online since 18 December 2018, connection on 13 April 2022. URL: http://journals.openedition.org/hybrid/465 ; DOI: https://doi.org/10.4000/hybrid.465

This text was automatically generated on 13 April 2022.

Revue Hybrid 


\title{
Depicting existentiality: the anarchic aesthetic of Désordre by Philippe De Jonckheere
}

\author{
Corentin Lahouste
}

From what point or stage in chaos does an extra disorder mark the beginning of order?

Éric Chevillard ${ }^{1}$

1 The main aim of Désordre, ${ }^{2}$ a website that Philippe De Jonckheere set up over fifteen years and continues to maintain, is to talk about (all of) life, to depict its tumultuous mess. It is a hypermedia piece with a star structure, that features semiotic hybridisation and crossovers between art forms, within a framework that oscillates between the autobiographical and the autofictional. It is like an online, polyphonic diary, primarily photographic, that reboots the practice of keeping a journal through the digital medium, using text, images and sound. The website includes numerous projects (often with constraints), and its progressive expansion process is nonteleological. In this article, we will attempt to highlight the anarchic aesthetic of Désordre in as much as it is at the heart of De Jonckheere's aim to depict existentiality; and to see how this aesthetic uses devices that are not only media-based, but also postural, poetic and symbolic.

2 Seven outstanding traits can be said to characterise Désordre as a project. We will review them, and show to what extent they can be said to be part of an anarchic aesthetic. This interpretation is supported by a reading of André Rezsler's L'Esthétique anarchiste (1973) and by Christiane Vollaire's article on “L'anarchie esthétique” (2005).

\section{Taking a stand against the "great man," the "Greatwriter," the master}

3 De Jonckheere is simplicity incarnate. He presents himself as a "normal" man, with a relatively traditional, banal life, with everyday issues to deal with (traffic jams, 
washing-up, hospital stays, ${ }^{3}$ to mention but three). De Jonckheere actually does have a day job in computers to "put food on the table" (in French: "faire bouillir la marmite"), according to an expression he uses frequently. He is light years away from the idea of the tortured, extraordinary artist exclusively invested in his creative process. An example is this blog entry that does not depict him in a very flattering light; the subject is his infectious phlebitis:

Fig. 1

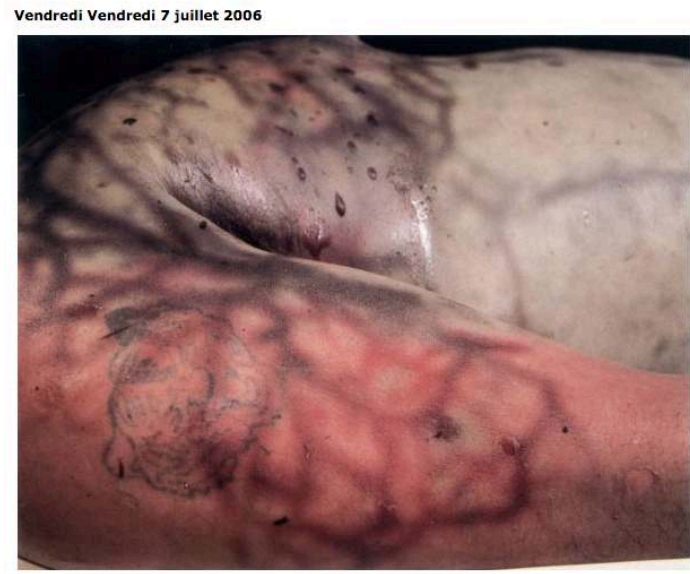

Les deux derniers jours mon bras gauche a enflé, on dirait même qu'il a deux fois le volume de

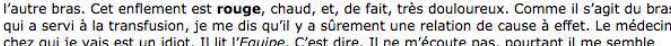
chez qui je vais est un idiot. II lit l'Equipe, C'est dire. Il ne m'écoute pas, pourtant il me semble
que j'aurais bien quelques informations à lui donner, mais son diagnostic était fait dés qu'ill a vus

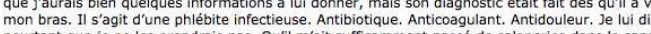
pourtant que je ne les prendrais pas. Qu'il m'ait suffisamment passé de saloperies dans le sang ces derniers jours que j'aimerais autant que possible, mais il ne m'écou
m'arrangerais avec le pharmacien $\& \# 151$ et puis un anti-inflammatoire.

N'empeche, j'ai beau dire, cela fait mal. Au point de ternir mon sommeil. De me fatiguer le soir et
d'influer en mauvaise part sur mon humeur, sur mon moral.

Et puis je repense à la récente vaccination de Nathan contre la rubéole, les oreillons et la ne s'était plaint de rien. Et comme cela arrive de teress

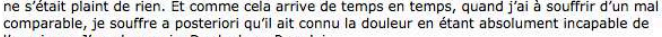
l'exprimer. J'en pleurerais. De douleur. Pour lui.

Photographie d'Andres Serrano

Screen capture of a page of Désordre.

4 It must be said that De Jonckheere is not shy about citing his influences. Through what he calls his "very small library," he plays with and works with the writings of those who made a mark on him (be it Perec, Beckett, or Cortázar). He posts extracts from writers he likes and admires on the Désordre website. He composes his own literary anthology by duplicating his physical library. He is helped with the site by web developer, Julien Kirch, whom he considers to be a co-author. Without Kirch, Désordre would never have taken shape the way De Jonckheere wanted. On one of the pages of the site, there is even a sort of vademecum of their joint work. The principle of cooperation and collaboration is at the heart of De Jonckheere's work, and completely undermines the idea of the solitary author. This aspect reflects the anarchist idea that "in the future, all works of art will be cooperative pieces." ${ }^{5}$ De Jonckheere also touches on the cooperation involved in getting his first novel, Une fuite en Égypte, (published in March $2017^{6}$ ) off the ground. He is never absolutely alone when he takes on a creative task.

Désordre also welcomes pieces and projects that are not created by De Jonckheere. The site is a meeting place, between the world De Jonckheere has created, and the work of other artists who are presented as "guests." One of the most beautiful pages on 
Désordre, according to De Jonckheere, Trois girafes et deux limaces, ${ }^{7}$ is by "guest" artist Thomas Deschamps. Finally, plenty of space is left for the reader-visitor-browser. Even though the visitor cannot leave comments under the elements posted by De Jonckheere, ${ }^{8}$ he or she can actively take part through hyperlinks, or the different games (memory) spread around the site, that represent, more than ever, the concept of open work developed by Umberto Eco. So, reading the site is a dynamic action, it becomes "lectacture" (read-action)," to use the term coined by Serge Bouchardon.

\section{Depicting "art where it happens"}

The second standout feature of the piece is its spontaneity, with the underlying idea that "the creative act is more important than the piece itself." through the use of the diary and in particular, Le bloc-note du Désordre ${ }^{11}$ (the Désordre notebook), the blog section of the site that goes behind the scenes (showing the nuts and bolts) of the creative process, giving an almost daily account of the events in De Jonckheere's life. The artist provides access to the backstage of his site (for example, the file tree), undermining the usual camouflage that is used to hide the workings of a website (lines of code in particular), making this a piece of "art en situation" (art, where it happens). The digital, technical set-up is visible, not unlike a "garage," ${ }^{12}$ where the tools are on display, often mentioned by De Jonckheere as the "archetypal place for art work." 13 "By showing the set-up, the creative process is reflected through the display of the manufacturing tools" and is, as Serge Bouchardon points out, "an important trend in electronic literature [of which Désordre is a part], that is constantly reflecting on gestures and tools, the presence and materiality of which rebound directly on the reading process. ${ }^{14}$ In addition, Désordre is a constant work in progress, it functions as a process rather than a finished piece: the journey is more important than the destination.

\section{Emphasising movement, change}

7 Anarchic art must, according to Rezsler, open up to the "eternity of metamorphoses." 15 The homepage of the Désordre website is a prototypical example of this principle. 
Fig. 2

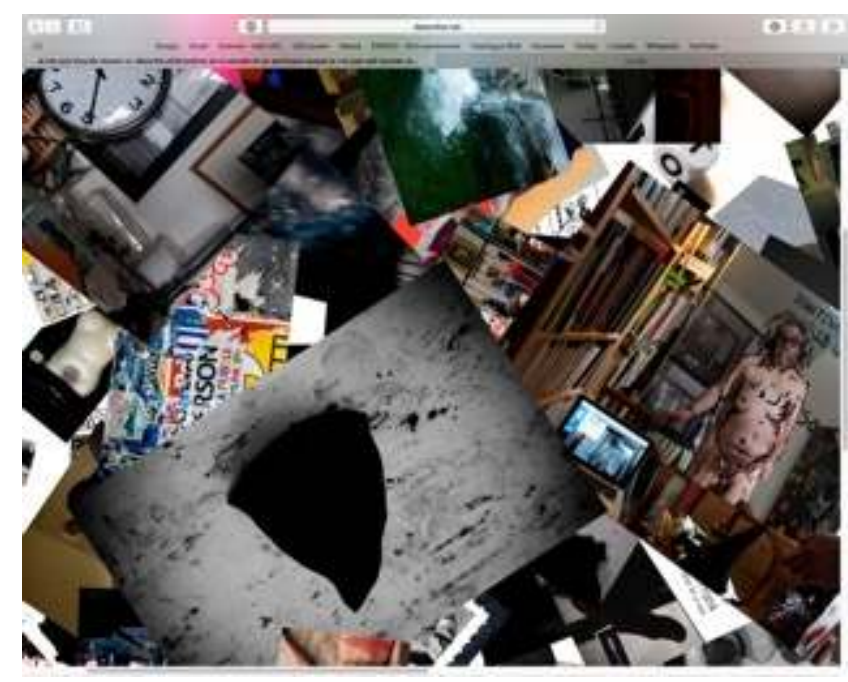

Screen capture of a page of Désordre.

In fact, it shows a collection of disparate images, a constellation of photographs, that constitute so many open doors to the different projects De Jonckheere has been working on for over 15 years, without any constraints of meaning or unity. The first impression is of an upturned drawer full of memories. But above all, the homepage is never the same, from one visit to the next, the images are in a different place with each refresh.

The Désordre homepage being what it is, it is extremely resistant to probability, and sends the user to any number of pages in a curious and arbitrary way, this means that no one ever sees the same thing on the Désordre website. [...] Not to mention that, no matter how many people are looking at this page, and even a number of the options on this page, it is highly unlikely that two visitors come across the same combination, even once. CQFD: this page cannot be shared on asocial media, you can't say, look at this! "this" only exists intermittently. And you can't imagine how happy that makes me. ${ }^{16}$

Désordre is a work of movement, a work in movement, marked by an aesthetic of flux and perpetual reconfiguration. A permanent and multidirectional flow, based on that of real life, following the principle of the perpetuum mobile-specific to human existence-, where nothing is ever set.

De Jonckheere works in the "fluidity of things," ${ }^{17}$ as Henri Michaux put it. This means that any reading (browsing, exploration) of/ in Désordre is a one-off experience. It is impossible to follow the same path through different pages on the site as it is in a constant state of metamorphosis, and one must be prepared to let go a little. De Jonckheere is clear that he wants the visitor to his site to get lost: "This site is not to be browsed in an orderly fashion, its name is a true indication. You must expect surprises and incoherence. ${ }^{18}$ Much of the meaning comes precisely from this drifting effect: the process takes over and propels the semantisation of the piece. The anomie is intentional, constructed.

11 The editorial form of Désordre as its name tells us, goes against the blog's usual imperatives of simplicity, stability and ease of handling. ${ }^{19}$ Digital technologies and screens expand the possibilities of any printed page-even the most inventive-and in De Jonckheere's hands, allow the visitor to see and feel a manifest and effective 
movement, as well as the creating a totally arbitrary process. The imperative identified by Rezsler, according to which "the (anarchic) work must allow for an infinite number of executions" ${ }^{20}$ absolutely applies to Désordre.

\section{Undermine the imposed, the conventional, the categorical}

Désordre circumvents traditional forms and rejects the principle of uniformization. The site is entirely dedicated to de-formatting and constant reconfiguration; it commits wholesale to destabilisation and transgression. De Jonckheere's project goes way beyond a strictly photographic or literary context. His work presents itself, like human existence itself, as a patchwork of a thousand and one elements collected and blended together. The textuality (a texture) is fundamentally hybrid, as the structure of the site is heterogenous, mixed, fragmented and open, managing to appear endless and inexhaustible. René Audet and Simon Brousseau, in an article that evokes the poetry of the diffraction of electronic writing, say Désordre provides "a baffling, complex browsing experience." ${ }^{21}$

13 It is, indeed, a labyrinthine piece run by a centrifuge, leading to spurts, breakouts and dispersion as opposed to centralism, in other words, it is run on an idea of periphery. The configuration of Désordre is based on both a rhizome and an archipelago, emphasizing movement over stillness and multiplicity and heterogeneity over the unitary and the uniform. The photograph on the site of a germinated potato, can be seen as a prototypical image.

Fig. 3

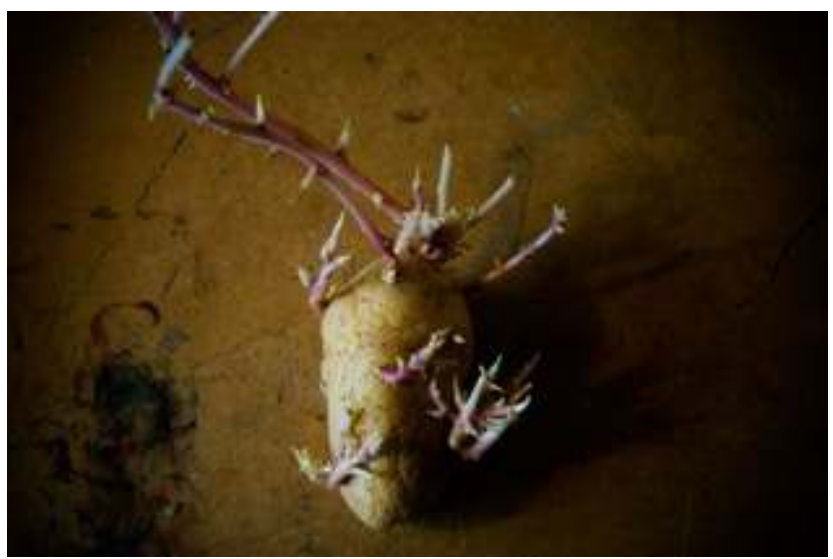

Screen capture of a page of Désordre

14 We should also note that this aspect of the work contains the seeds of a critical and political perspective on dominant market forces in contemporary society that uniformize, frame and make things "appropriate." Désordre deconstructs and wrecks this process. Désordre is a place for experimentation. A good example is the "Ursula" project, a recent addition to the site. ${ }^{22}$ The underlying energy of the site comes from constantly trying something new, making something happen, committing to the unknown. "To stride around your own personal scrubland without ever trying to find your way, and especially without ever worrying about finding your way back," ${ }^{23}$ is how 
De Jonckheere puts it in an homage to Samuel Beckett. So, the concept of formlessnessas illustrated by the photograph of the potato we mentioned earlier-seems to be pertinent here. The idea of plasticity and malleability of the content that has slowly built up on the site is key, and the same image can be used in different projects; similarly, certain projects follow an evolving process. The material on the site is constantly being reorganised, opening new paths. As reader-explorers, we are struck by its polymorphism and persistent uncertainty.

\section{Refusing any form of aesthetic hierarchy}

The fifth trait refers to the anarchic idea, that initially came from the Dadaists in the early 20th century, followed by Fluxus, that says that anything can be a work of art. As Béatrice Bonhomme puts it, "there is no hierarchy among real things, it is more a question of the weight of existence, the weight of presence." ${ }^{24}$ Désordre presents itself as a mish-mash that collects, mixes, makes hybrids and decompartmentalizes artistic practices. The site is a sedimented space, made of various, multiple materials, piled and rearranged in a mix that can be confusing at times. In this, the work is similar to that of the poet Valérie Rouzeau who "accumulates everything from life in a jumble, blurring paths and borders." ${ }^{25}$ Just like René Audet says, Désordre is a "node of diverse resources, from different media; photos, video, sound files, dialogue with the text, built on the basis of an intratextuality that justifies the network of links woven around the work." 26

The randomness that is at the core of the work is part of the horizontal perspective specific to anarchic art. In fact, there is an equal place, an exhibition space, for each piece of site content. As De Jonckheere, claims on the homepage, the reader-browser has access to all of the projects. Désordre, in this way, can be compared to a constellation-an image De Jonckheere himself uses, run on radical freedom, where new paths must be taken, new trails must be forged, that one can always (and is encouraged to) turn away from and come back to at a later date. It is a work shaped by disconnection, a work of discontinuation. René Audet assures us that "continuity is diverted by the multiplication of windows, and screens, as much as by the constraints of the platforms." ${ }^{27}$ For the reader-browser, the poetic characteristic echoes the ontological experience of the multiple layers of human existence. As Michael Sheringham tells us "the space we live in (as opposed to theorize) is not homogeneous or uniform. Spatial experience is discontinuous: we are constantly shuttling between different kinds of space, separated by (what Perec calls) 'fissures, hiatuses, friction points." ${ }^{28}$ On the subject of time, Jean-François Hamel, put forth that the historical regime specific to our modernity was spectral, that it worked by recurrences and that as a result, the past-present-future in no way constituted a smooth, regular continuum. The open instability of modern consciousness is that of a fractured world; one that is magnificently represented in Désordre.

\section{Promoting the real "in its most immediate and most naked physicality" 29}

De Jonckheere's work appears exemplary in this regard, in particular in as much as it can be considered as an everyday work. ${ }^{30}$ The different projects he has undertaken 
constantly deal with the infra-ordinary. Some of the titles underline this aspect: "Le quotidien" (The everyday), "Le petit journal" (The little newspaper), and "Février" (February). In them, he exalts the "nothing special," the "almost nothing," in the same way he highlights life's composite, multicoloured character, as in "La vie (comme elle va)," a project in the form of superimposed, disparate photographs, that follows an existential, non-organised path: a constellation of feelings that depicts a stringy, emotional and memorial landscape.

Fig. $4 \& 5$
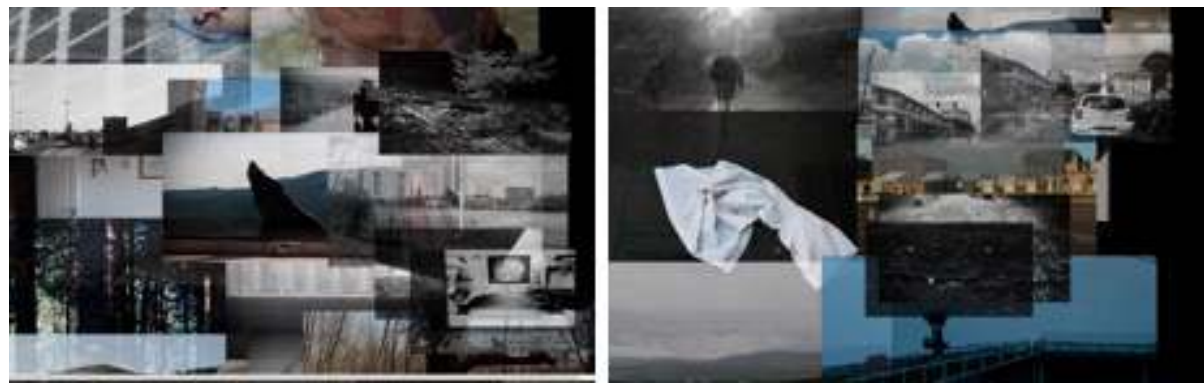

Screen capture of La vie comme elle va (Toute la vie).

In Désordre, a work made from "a thousand 'little nothings' the arbitrary succession of which makes up everyday life," ${ }^{31}$ attention is paid to detail, to the anecdotal, to the unnoticed. It is marked by "the issue of the minuscule" ${ }^{32}$ and follows in the footsteps of Georges Perec, whose influence De Jonckheere readily recognises. ${ }^{33}$ Désordre explores everyday life, and is located below the extraordinary and the spectacular.

[...] it is the fragile hope, not to retain a little of what flows by, that would be too far-fetched, but to keep a spotlight on that which remains yet stays in the shadows, a shadow that gets thicker as new, equally miniscule events take place and pile on top of them and as just as incapable of emerging from the undifferentiated mass of time in which that which we forget becomes mired. ${ }^{34}$

19 The idea is to relaunch a sensorial dynamic, as is evident from a number of photographic montages created by De Jonckheere, that are not dissimilar to his teacher, Barbara Crane's work. ${ }^{35}$

Fig. $6 \& 7$
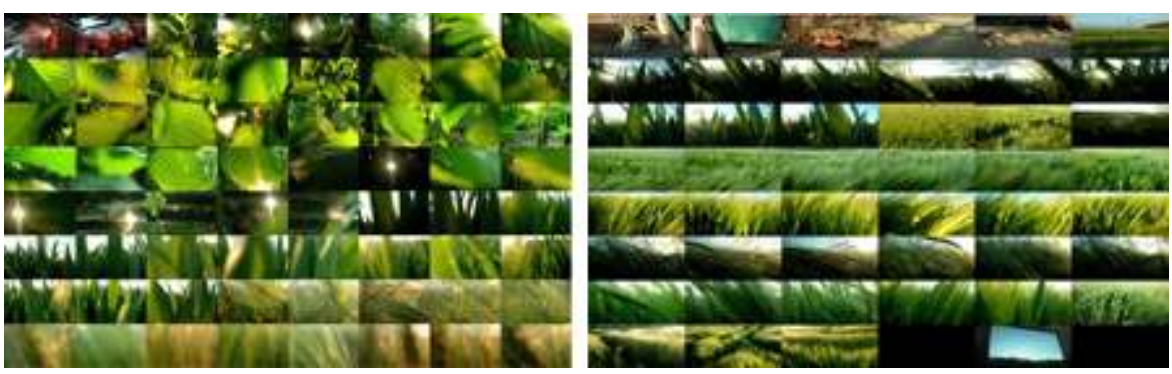

Screen capture of the project Les rigaudières - mai 2004.

Désordre appears thus as a space where the real becomes deeper, leading to what Guillaume Le Blanc calls a "reality invented by practices of the ordinary that are contaminations of the real by the possible." ${ }^{36}$ The everyday is an "arena of endless difference, ${ }^{37}$ as a place with no hierarchy, "it is also potentially the present, alive with 
the force of lived but uncategorizable experience," ${ }^{38}$ to use Michael Sheringham's words in Everyday life. Désordre commits to the "anarchy of its chiaroscuro," to quote Lukács. ${ }^{39}$ Through his different projects, De Jonckheere stimulates the experience of proximity, where one must detect Herman Parret's "shivers of the sublime." He causes what Gilles Clément called "involuntary art" to spout out, art that "floats on the surface of things"; art with no artist that comes from the "happy result of an unplanned combination of situations or objects organised among themselves according to the rules of harmony dictated by chance." ${ }^{40}$

Fig. 8

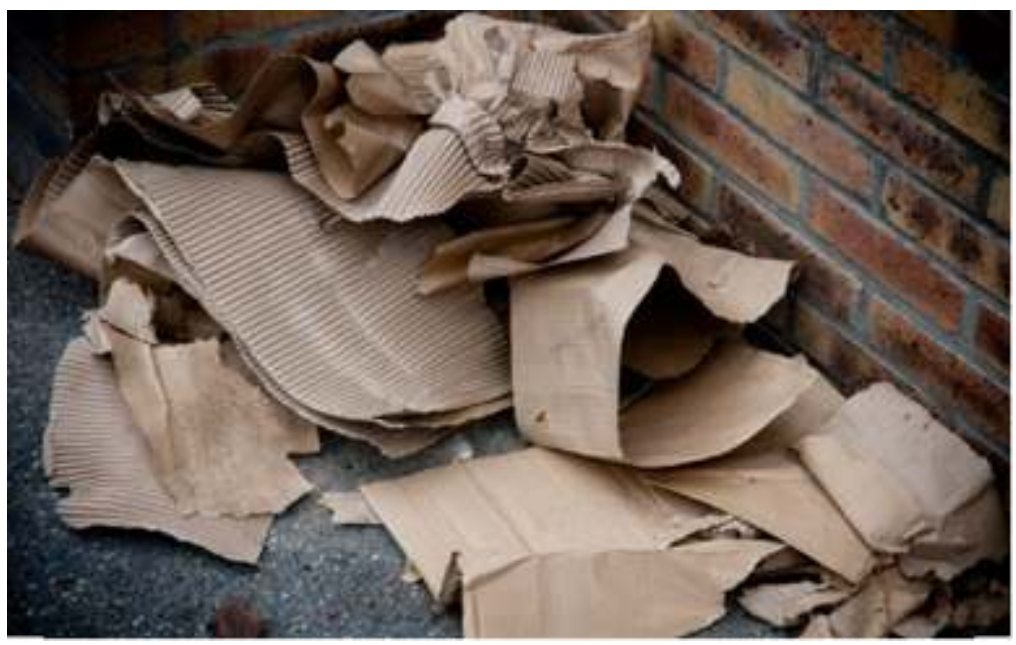

Screen capture of a page of Désordre

21 Following the path forged by Perec, De Jonckheere aims to "tame the everyday, to turn it into the material of the poetry of the prosaic ${ }^{41 "}$; he attempts to bring to life the emotional resonances that can occur between a subject and its surroundings. De Jonckheere starts with the real, but aestheticizes it through different media (for example, the criss-cross of mini photos on the screen, that changes into an abstract mosaic). Indeed, the site becomes a specific space where feelings are reconfigured, using very diverse media. He brings out the sensitive, sensorial and highly emotional dimension of the experience of daily life, in an almost rough and immediate manner. He turns the everyday back into an experience-an experience-based space-a place that is "affectualised." The artist-of-all-trades carries out a "subjective takeover" of everyday life, which is placed "on the level of experience, and the most personal experiences, ${ }^{42}$ to quote Pierre Macherey: the idea is to rehabilitate the everyday as a place of feelings, and to feel it.

\section{Abolishing the distinction between art and life}

Désordre is a work where the frame dissolves, is dissolved-where the very concept of a frame is rendered inoperative: you never really know where the piece is going as it sends you off to other websites, to other artistic projects and works, and, initially, toward Philippe De Jonckheere's own life. In addition, by using hyperlinks, it is constantly projecting outwards, always dragging the reader elsewhere. This lack of 
fences of the work is reminiscent of what Samuel Archibald called the third moment of the hypertextual doxa. ${ }^{43}$

But it is as a work of the everyday that Désordre abolishes the distinction between art and life, the final trait of anarchic aesthetics that applies to the piece and makes it stand out from most other hypermedia works. We could even refer to the site as a lifepiece that, as it delves into the profusion and multiplicity of the everyday, wants to be a "place that is open to the germination of possibilities," 44 an "opening toward infinite spaces," ${ }^{45}$ according to the phrase used by De Jonckheere himself.

To sum up, Désordre opens up to new modalities of existence, essentially driven by passion and aesthetics, through the anarchic-aesthetic reconfiguration of human existence it implements and proposes. The artistic freedom of Désordre-its refusal to be formatted, and its hybrid, experimental nature can be seen as part of the "free dissemination of existence" that Jean-Luc Nancy mentioned, adding that it is not "the diffraction of a principle, neither is it the multiple effect of a cause, but the anarchy of a singular rising, that is, as such, plural in essence." ${ }^{46}$ Désordre thus brings freedom to art, as it brings freedom to the relationship to existence-art and existence are seen by it to be fundamentally free, or freed. The anarchic aesthetic constitutes the poetic principle but also the ontological principle that allows us to gain a better grasp of De Jonckheere's work, that constantly emphasises emancipation and reinvention, two of the core values of the libertarian movement, keeping both in perpetual movement.

\section{BIBLIOGRAPHY}

ARCHIBALD Samuel, Le Texte et la technique. La lecture à l'heure des médias numériques, Montréal, Le Quartanier, 2009.

AUDET René, "Écrire numérique: du texte littéraire entendu comme processus," Itinéraires, “Textualités numériques," 2015. [Online] https://www.rechercheisidore.fr/search/resource/? uri=10670/1.1q74rt [accessed 3 April 2018].

AUDET René and BRousSEAU Simon, "Pour une poétique de la diffraction de l'œuvre littéraire numérique: l'archive, le texte et l'œuvre à l'estompe," Protée, vol. 39, no. 1, Spring 2011, p. 9-22. BonHomme Béatrice, CASTROE Idoli and Lloze Évelyne, Dire le réel aujourd'hui en poésie, Paris, Hermann, 2016.

BOUCHARDON Serge, "Chapitre III. Les œuvres de littérature numérique," Un laboratoire de littératures. Littérature numérique et Internet, Paris, Bibliothèque publique d'information, 2007. [Online] http://books.openedition.org/bibpompidou/232 [accessed 3 April 2018].

BuRGelin Claude, Georges Perec, Paris, Seuil, 1988.

CHEVILlard Éric, L'Autofictif. Journal 2007-2008, Talence, L'Arbre vengeur, 2008.

CLÉMENT Gilles, “L'esthétique du 'tas de bois' ou traité succinct de l'art involontaire," in PoNS Gilbert (dir.), Le Paysage: sauvegarde et création, Seyssel, Champ Vallon, 1999, p. 121-123. 
Couleau Christèle and HelléGouARC'H Pascale (dir.), Les Blogs. Écritures d'un nouveau genre?, Paris,

L'Harmattan, 2010.

DE JONCKHEERE Philippe, [s.d.] “Commencement à toutes fins utiles,” Désordre. [Online] https:// www.desordre.net/textes/bibliotheque/auteurs/beckett/beckett.pdf [accessed 3 April 2018].

DE JONCKHEERE Philippe, [s.d.] Désordre. [Online] http://www.desordre.net [accessed 24 April 2018].

LAHOUSTE Corentin, “Les sens du quotidien, l'essence du quotidien. Désordre de Philippe

De Jonckheere," in Contemporary French \& Francophone Studies: Sites, to be published in 2018.

LE BLANC Guillaume, Les Maladies de l'homme normal, Paris, Passant ordinaire, 2004.

LUKÁCS Georg, L'Âme et les Formes [1911], translated by Guy Haarscher, Paris, Gallimard, 1974.

MACHEREY Pierre, Petits Riens. Ornières et dérives du quotidien, Lormont, Le bord de l'eau, 2009.

MichauX Henri, Passages [1950], Paris, Gallimard, 1963.

NANCY Jean-Luc, L’Expérience de la liberté, Paris, Galilée, 1988.

RESZLER André, L'Esthétique anarchiste, Paris, Presses Universitaires de France (PUF), 1973.

SHERINGHAM Michael, Traversées du quotidien. Des surréalistes aux postmodernes, Paris, Presses Universitaires de France (PUF), 2013.

Simotas Spyrodon, "Désordre de Philippe De Jonckheere, fracas visuel dans l'espace-mémoire," in Colloque international des études françaises et francophones des $\mathrm{XX}^{e}$ et $\mathrm{XXI}{ }^{e}$ siècles - Le sens et les sens, Bloomington, 2017, [s.é.].

Vollaire Christiane, “L'anarchie esthétique," Lignes, no. 16, 2005/1, p. 160-169.

\section{NOTES}

1. Eric Chevillard, L'Autofictif. Journal 2007-2008, Talence, L'Arbre vengeur, 2008, p. 80.

2. Philippe De Jonckheere (s.d.). Désordre. [Online] http://www.desordre.net [accessed 3 April 2018].

3. See Philippe De Jonckheere (s.d.). Désordre. [Online] http://www.desordre.net/photographie/ polaroid/15-s1/15-s1.html [accessed 24 April 2018].

4. See Philippe De Jonckheere (s.d.). Désordre. [Online] http://www.desordre.net/textes/ bibliotheque/ [accessed 24 April 2018].

5. André Reszler, L'Esthétique anarchiste, Paris, Presses Universitaires de France (PUF), 1973, p. 42.

6. See Qui ça? : J-91 et J-25. [Online] http://www.desordre.net/bloc/ursula/2017/index.htm [accessed 24 April 2018].

7. See Philippe De Jonckheere (s.d.). Désordre. [Online] https://www.desordre.net/invites/ thomas_deschamps/girafesetlimaces.htm [accessed 24 April 2018].

8. See Christèle Couleau and Pascale Hellégouarc'h (dir.), Les Blogs. Écritures d'un nouveau genre?, Paris, L'Harmattan, “Itinéraires. Littérature, textes, cultures," 2010, p. 183.

9. Serge Bouchardon, «Chapitre III. Les œuvres de littérature numérique », Un laboratoire de littératures. Littérature numérique et Internet, Paris, Bibliothèque publique d'information, 2007, p. 22. [Online] http://books.openedition.org/bibpompidou/232 [accessed 3 April 2018].

10. André Reszler L'Esthétique anarchiste, Paris, Presses Universitaires de France (PUF), 1973, p. 6.

11. See Philippe De Jonckheere (s.d.). Désordre. [Online] https://www.desordre.net/blog/ [accessed 24 April 2018]. 
12. Voir Philippe De Jonckheere (s.d.). Désordre. [Online] https://www.desordre.net/labyrinthe/ garage/photos/vignettes/index.htm et http://www.desordre.net/labyrinthe/divers/ desordre_pas_accueillant.html [accessed 24 April 2018].

13. Spyrodon Simotas, "Désordre de Philippe De Jonckheere, fracas visuel dans l'espace-mémoire," Colloque international des études françaises et francophones des $\mathrm{XX}^{e}$ et $\mathrm{XXI}^{e}$ siècles - Le sens et les sens, Bloomington, 2017.

14. Serge Bouchardon, "Chapitre III. Les œuvres de littérature numérique," Un laboratoire de littératures. Littérature numérique et Internet, Paris, Bibliothèque publique d'information, 2007, p. 33. [Online] http://books.openedition.org/bibpompidou/232 [accessed 3 April 2018].

15. André Reszler, L'Esthétique anarchiste, Paris, Presses Universitaires de France, 1973, p. 6.

16. Voir Philippe De Jonckheere (s.d.). Désordre. [Online] http://www.desordre.net/ photographie/numerique/quotidien/titre.htm [accessed 24 April 2018].

17. Henri Michaux, Passages [1950] Paris, Gallimard, 1963, p. 80.

18. Philippe De Jonckheere, “À l'aide !," Désordre, December 2006. [Online] https:// www.desordre.net/accessoires/questions/aide.htm [accessed 15 April 2017].

19. Voir Etienne Candel, "Penser la forme des blogs, entre générique et génétique," in Christèle Couleau and Pascale Hellégouarc'h (dir.), Les Blogs. Écritures d'un nouveau genre?, Paris, L'Harmattan, 2010, p. 26.

20. André Reszler, L’Esthétique anarchiste, Paris, Presses Universitaires de France (PUF), 1973, p. 90 .

21. René Audet and Simon Brousseau, "Pour une poétique de la diffraction de l'œuvre littéraire numérique: l'archive, le texte et l'œuvre à l'estompe," Protée, vol. 39, no. 1, Spring 2011, p. 17.

22. See Philippe De Jonckheere (s.d.). Désordre. [Online] https://www.desordre.net/bloc/ursula/ 2017/textes/083.htm [accessed 24 April 2018].

23. Philippe De Jonckheere (s.d.). "Commencement à toutes fins utiles," Désordre. [Online] https://www.desordre.net/textes/bibliotheque/auteurs/beckett/beckett.pdf [accessed 3 April 2018].

24. Béatrice Bonhomme, Idoli Castroe and Évelyne Lloze, Dire le réel aujourd'hui en poésie, Paris, Hermann, 2016, p. 434.

25. Évelyne Lloze, “La poésie à l'épreuve du dire. L'expérience ordinaire: Antoine Emaz \& Valérie Rouzeau," in Béatrice Bonhomme, Idoli Castroe and Évelyne Lloze (dir.), Dire le réel aujourd'hui en poésie, Paris, Hermann, 2016, p. 477.

26. René Audet, "Écrire numérique: du texte littéraire entendu comme processus," Itinéraires, “Textualités numériques," 2015, p.6. [Online] https://www.rechercheisidore.fr/search/ resource/?uri=10670/1.1q74rt [accessed 3 April 2018].

27. René Audet, "Écrire numérique: du texte littéraire entendu comme processus," Itinéraires, “Textualités numériques," 2015, p.6. [Online] https://www.rechercheisidore.fr/search/ resource/?uri=10670/1.1q74rt [accessed 3 April 2018].

28. Michael Sheringham, Everyday life. Theories and practices from the surrealists to the present, Oxford, Oxford University Press, 2006.

29. Christiane Vollaire, "L'anarchie esthétique," Lignes, no. 16, 2005/1w, p. 167.

30. See Corentin Lahouste, "Les sens du quotidien, l'essence du quotidien. Désordre de Philippe De Jonckheere," in Contemporary French \& Francophone Studies : Sites, to be published in 2018.

31. Pierre Macherey, Petits Riens. Ornières et dérives du quotidien, Lormont, Le bord de l'eau, 2009, p. 235.

32. See Philippe De Jonckheere (s.d.), Désordre. [Online] http://www.desordre.net/bloc/ pourquoi.html [accessed 24 April 2018].

33. The connection to Perec is obvious in De Jonckheere's work, notably with regard to constraints. The writer of Life, a user's manual is one of the few authors that feature in what appears to be De Jonckheere's literary pantheon (http://www.desordre.net/textes/bibliotheque/ 
auteurs/), and a number of his projects are presented as homages to Perec's work. For example, "Je me souviens de Je me souviens de Georges Perec" (http://www.desordre.net/textes/ bibliotheque/auteurs/perec/je_me_souviens.html) or "Tentative d'épuisement de Tentative d'épuisement d'un lieu parisien de Georges Perec" (http://www.desordre.net/textes/ bibliotheque/auteurs/perec/saint-sulpice.html). Perec's work is a major intertext in Désordre.

34. See Philippe De Jonckheere (s.d.). Désordre. [Online] http://www.desordre.net/bloc/ pourquoi.html [accessed 24 April 2018].

35. The photographer is one of the "guests" on the site.

36. Guillaume Le Blanc, Les Maladies de l'homme normal, Paris, Passant ordinaire, 2004, p. 211.

37. Michael Sheringham, Everyday life. Theories and practices from the surrealists to the present, Oxford, Oxford University Press, 2006, p. 22.

38. Michael Sheringham, Everyday life. Theories and practices from the surrealists to the present, Oxford, Oxford University Press, 2006, p. 17.

39. Georg Lukács, L’Âme et les Formes [1911], translated by Guy Haarscher, Paris, Gallimard, 1974, p. 247.

40. Gilles Clément, "L'esthétique du 'tas de bois' ou traité succinct de l'art involontaire," in Gilbert Pons (dir.), Le Paysage: sauvegarde et création, Seyssel, Champ Vallon, 1999, p. 121.

41. Claude Burgelin, Georges Perec, Paris, Seuil, 1988, p. 37.

42. Pierre Macherey, Petits Riens. Ornières et dérives du quotidien, Lormont, Le bord de l'eau, 2009, p. 19.

43. See Samuel Archibald, Le Texte et la technique. La lecture à l'heure des médias numériques, Montréal, Le Quartanier, 2009.

44. Pierre Macherey, Petits Riens. Ornières et dérives du quotidien, Lormont, Le bord de l'eau, 2009, p. 21.

45. Philippe De Jonckheere (s.d.), "Commencement à toutes fins utiles," Désordre. [Online] https://www.desordre.net/textes/bibliotheque/auteurs/beckett/beckett.pdf [accessed 3 April 2018]

46. Jean-Luc Nancy, L'Expérience de la liberté, Paris, Galilée, 1988, p. 16 sq.

\section{ABSTRACTS}

Tell (almost everything about) life and report its utter shambles, this is what is mostly at stake in Désordre, hypermediatic work created, developed and fuelled by Philippe De Jonckheere since the early years 2000. Through this article, we shall highlight seven salient features of anarchic aesthetics of Désordre, as the main focus of De Jonckheere is to depict existentiality. We can see in his work how this specific aesthetics relies not solely on media mechanisms, but also on postural, poetic and symbolic features.

\section{INDEX}

Keywords: anarchic aesthesic, contemporary poetic, Désordre, hypermediatic literature, Philippe De Jonckheere 


\section{AUTHOR}

\section{CORENTIN LAHOUSTE}

Corentin Lahouste is a researcher at Université catholique de Louvain (Belgium), within the Centre de recherche sur l'imaginaire (CRI). He prepares, under the co-direction of prof. Myriam Watthee-Delmotte (UCL) and prof. Bertrand Gervais (UQAM, Montréal), a Ph.D. thesis dedicated to figures, forms and postures of anarchy in French contemporary literature. His research focuses on the work of Marcel Moreau, Yannick Haenel and Philippe De Jonckheere (hypermedia). Started in the context of the Interuniversity Attraction Pole program "Literature and Media Innovation," it currently continues through the mandate of research fellow ('aspirant') of the Belgian Fonds National de la Recherche Scientifique (FNRS). He had the opportunity to publish the findings of his works in the form of articles in journals such as Les Lettres Romanes, Studi Francesi, Fixxion, or Mémoires du livre/Studies in Book Culture. 